\title{
Metabolic Syndrome (MetS) Prevalence, Associated Factors and Nutritional Practices in the Type 2 Diabetes Mellitus Patients
}

\author{
Nasser I. E. Abo ELNaga ${ }^{1}$, Samir M. Ahmed ${ }^{1}$, Neveen F. M. Agamy ${ }^{2}$, Marwa R. A. Elbakatoshy ${ }^{1}$
}

\begin{abstract}
Aim: The aims of this study were to determine the prevalence of metabolic syndrome (MetS) and its associated factors among type 2 diabetes patients and to study the most important nutritional practices among them.

Materials and Methods: The study was included 100 patients with type 2 diabetes it was conducted at the Diabetes Centers in Alexandria Hospitals, Egypt, from June 2018 to February 2019. The study included the use of a questionnaire to obtain some information about diabetic patients, such as socioeconomics Characters, medical history of diabetes their most important nutritional practices, Waist circumference was done. Also, the blood samples were collected to measure some biochemical parameters; fasting blood glucose, lipid profile \{total cholesterol (TC), triglyceride (TG), high-density lipoprotein cholesterol (HDL-C)\}, and blood pressure level. MetS was defined according to the criteria of the NCEP/ATP III to include individuals with any three or more of the five components.

Results: Data showed that the prevalence of MetS in the sample was $71 \%$ and $29 \%$ was non-metabolic syndrome. High fasting blood glucose was the most common risk factor, followed by Waist circumference (65\%), high TG (47\%), lowed HDL (39\%).

The studying of the nutritional practices showed that the metabolic syndrome patient preferred baking (24\%) and boiling (17\%) while $(9 \%)$ of non- metabolic syndrome preferred boiling. On the other hand, $(28 \%)$ of the total patients preferred baking in oven, and the metabolic syndrome patients preferred fruit $(\mathbf{3 1 \%})$ and sweets $(\mathbf{1 8 \%})$ between meals, while (19\%) of non-metabolic syndrome patients preferred fruit and $(5 \%)$ preferred vegetables between meals. Also, the study showed that $12 \%$ of metabolic syndrome patients had a poor level of practices, and $14 \%$ had good practices, $45 \%$ moderate nutritional practices.
\end{abstract}

Our findings indicated that metabolic syndrome had become a common public health problem, and therefore, we need to develop strategies, which aim to prevent and treat the of metabolic syndrome.

Key Words: Metabolic syndrome, predictive risk factors, type 2 diabetes, Nutritional Practices.

DOI: 10.21608/ASEJAIQJSAE.2020.91324

${ }^{1}$ Food and Human Nutrition, Home Economics Department,

Faculty of Agriculture, University of Alexandria.

${ }^{2}$ Food Analysis and Safety, High Institute of Public Health,

Alexandria University.

Received April 1, 2020, Accepted, May 17, 2020.

\section{INTRODUCTION}

Metabolic syndrome (MetS) is defined as a cluster of glucose intolerance, hypertension, dyslipidemia and central obesity with insulin resistance as the source of pathogenesis. Although several different combinations of criteria have been used to define metabolic syndrome, a recently published consensus recommended the use of ethnic specific criteria, including waist circumference as an indicator of central obesity, triglyceride and high density lipoprotein cholesterol (HDL) as indicators of dyslipidemia and blood pressure greater than $130 / 85 \mathrm{mmHg}$ (Shin et al., 2013).

The hyperglycemic condition in diabetics makes them able to develop some complications which contribute to the morbidity. The susceptibility of diabetics to complications is driven by both modifiable and non modifiable risk factors. Currently, there is heightened interest in a cluster of some risk factors called metabolic syndrome (MetS) that predicts cardiovascular disease and type 2 diabetes mellitus (Lorenzo et al., 2003). It comprises the following major characteristic: Hypertriglyceridemia, low levels of highdensity lipoprotein-cholesterol (HDL-C), central (abdominal) obesity, hypertension and concomitant insulin resistance/glucose intolerance (Alberti et al., 2006).

Metabolic syndrome (MetS) is associated with a three to five fold increased risk for the development of type 2 diabetes mellitus (Wilson et al., 2005). According to Lesser et al. (2014), knowledge regarding diet can change the unfavorable dietary pattern among the diabetic patients. Positive attitude towards dietary management may be control the blood glucose level among diabetic patients (Wang et al., 2014). Proper practices according to the dietary recommendation prevent further complications of diabetes (Negrato et al., 2014).

The MetS is known to be caused by insulin resistance or insulin resistance-linked obesity, a condition whereby the body's cells are incapable of 
taking up glucose from the blood. Insulin resistancelinked obesity is caused by poor dieting and lack of regular exercise. Other genetic or lifestyle risk factors as predictor variables equally lead to the metabolic MetS. They are increasing the factors of MetS by the age (greater than 40 years), smoking of cigarette, alcohol intake, overweight, sedentary life-style and family history of type 2 diabetes (Ferrannini., 1995, Walker., 2006).

In managing the type 2 diabetes of patients' lifestyle and dietary pattern, changes must be required. This change should be influenced by one's attitude, knowledge and practices; therefore, it is necessary to know about the risk factors in an effective way before managing the diabetes type 2 patients as these major determinants will help to treat the T2DM (Nsiah et al., 2015).

The American Diabetes Association (ADA) recommended that diabetic patients need to be aware of their nutrition requirements; as carbohydrates should be $45 \%-65 \%$ of daily total caloric intake. The kind of carbohydrates such as fruits, green leafy vegetables, whole grains and beans are important. Fats should be 25 $\%-35 \%$ of the daily caloric intake. It is preferred to take skimmed or low-fat dairy instead of whole milk products. Protein should be $12-20 \%$ of the daily calories although this may differ depending on a patient's requirement of health (American Heart Association., 2012).

MetS and T2DM are associated with risks of cardiovascular disease (CVD) and other related disorders. One major underlying cause of CVD in patients with MetS or T2DM is a characteristic form of atherogenic dyslipidemia (Ginsberg and MacCallum., 2009).

Aim: The aims of this study were to determine the prevalence of metabolic syndrome (MetS) and its associated factors among type 2 diabetes patients and the most important nutritional practices among them.

\section{MATERIALS AND METHODS}

\section{Subjects}

This study was conducted between June 2018 and February 2019 in the Diabetic Centers of Alexandria hospitals. One hundred (100) Type 2 diabetics participated in this study as a case study (18 males and 82 females).

Their ages ranged between 20 years to more than 60 years. A questionnaire was used to collect the study information data from the diabetic patients sample; namely; the, Socioeconomics Characters, medical history of diabetics and the most important nutritional practices and their food habits. Participants were fasted over night before blood sample. Blood samples were collected by hospital nursing to measure some biochemical parameters: fasting blood glucose and a lipid profile in the hospital laboratory.

\section{Nutritional practices}

To study nutritional practices, 11 questions were prepared and scores were given to the questions according to the correctness and error of the answer, where (3) was given to the good, (2) to the moderate and (1) to the weak, and the highest score for the respondent was 29 and the lowest score is 15 , according to his answers. Three levels by calculating the range and dividing it by 3 , giving 15-19 for the weak, 20 -24 for the moderate, and 25- 29 for the good.

\section{Blood Sample Collection and Processing}

About $5 \mathrm{ml}$ of venous blood samples were collected by the hospital nurse after fasting overnight. The sample was taken to the hospital laboratory; Blood samples were received into clean dry centrifuge tubes and left to clot at room temperature, then centrifuged for 10 minutes at 3000 R.P.M to separate the serum. Serum was carefully aspirated and transferred into clean covet tee tubes and stored frozen at $-20^{\circ} \mathrm{C}$ for analysis (Malhotra, 2003). Parameters that were determined included: fasting blood glucose (FBG), Lipid Profile (Total cholesterol (TC), triglyceride (TG), high-density lipoprotein cholesterol (HDL-C) and low-density lipoprotein cholesterol (LDL-C), The blood pressure and the anthropometric variables were measured.

\section{Biochemical parameters}

lipid profiles:

\section{i. Tri glycerides (T.G):}

Serum triglycerides (T.G) were measured using the modified kinetic method according to the method described by Fossatiand Principe (1982).

\section{ii. Total cholesterol (T.C):}

Serum cholesterol was measured using the modified kinetic method according to Richmond (1973).

\section{iii. High density lipoprotein cholesterol (HDL-C):}

Serum high density lipoprotein cholesterol (HDL-C) was measured using the modified kinetic method according to Allain (1974)

\section{Waist circumference measurements:}

The waist circumference of the sample was measured to the nearest $0.1 \mathrm{~cm}$ using a tape measure midway between the lower corner of the ribs and the top of the suprailiac crest.

\section{Metabolic Syndrome Definition:}

Metabolic syndrome was defined according to the criteria to have "MetS" of the National Cholesterol Education Program / Adult Treatment Panel (NCEP/ATP III) which assumes that individuals with 
any three or more of the following five components have MetS: (1) Abdominal obesity according to (Waist circumference $>102 \mathrm{~cm}$ for men or $>88 \mathrm{~cm}$ for women), (2) high TG $\geq 1.7 \mathrm{mmol} / \mathrm{L}$. (150 mg/dl.), (3) low HDLC: Men $<0.9 \mathrm{mmol} / \mathrm{L}(<40 \mathrm{mg} / \mathrm{dl})$ or women $<1.0$ $\mathrm{mmol} / \mathrm{L}(<50 \mathrm{mg} / \mathrm{dl})$, (4) high blood pressure (systolic $\mathrm{BP} \geq 130 \mathrm{~mm} \mathrm{Hg}$ or diastolic $\mathrm{BP} \geq 85 \mathrm{~mm} \mathrm{Hg}$ or treatment of hypertension and (5) high $\mathrm{FBG} \geq 6.1$ $\mathrm{mmol} / \mathrm{L}(110 \mathrm{gm} / \mathrm{dl})$ ((Lorenzo et al., 2003).

\section{Statistical Analysis}

The quantitative data are expressed as means \pm standard deviation and t-test was used to a significance of the for differences in two mean values of grouped data. Qualitative data are expressed as percentage and Chi square test is used for comparison. A level of significance $5 \%$ was considered as statistically significant. By using SPSS (version 20.0) of statistical software.

\section{RESULTS AND DISCUSSION}

\section{Prevalence of the individual components of MetS Type 2 diabetic Patient}

Table (1) explains the prevalence of the individual components of MetS Type 2 diabetic patient, the overall prevalence percentage of MetS was71\%, for the overall population, high fasting glucose level was the commonest component $(71 \%)$ of the MetS, followed by high waist circumference (65\%), high TG (47\%) and lowered HDL (39\%).

Chandalia et al.,( 2000) found that in females, the most common component was waist circumference, followed by, high triglycerides, and this may be due to lack of physical activity, high stable lifestyle, and eating at night. Furthermore, it was found that waist circumference and lowered HDL-C prevalence were significantly higher in females than males. It is well documented that lowered HDL-C levels are associated with an increased risk of coronary heart diseases or cardiovascular diseases.

This result is disagreement with Felix-Val et al. in (2008) who, using the NCEP/ATP III, they found that hypertension was the commonest in males, followed by hyper triglyceridemia.

A number of possible mechanisms can explain the inverse relationship between increased triglycerides in cases of insulin resistance and increased HDL undermining, leading to lower plasma HDL concentrations. One possibility is the decreased activity of lipoprotein lipase (LPL), which will have an effect on weak maturity of HDL molecules. It has been shown that normal insulin-mediated stimulation of LPL activity decreased insulin resistance (Moebus et al., 2007). In type 2 diabetes, especially when blood sugar control is weak and in patients with relatively insulin deficiency, LPL activity is reduced (Grundy et al., 2005).

People with low glucose tolerance and type 2 diabetes tend to have high triglycerides in the blood (hypertriglyceridemia) in addition to further increasing in HDL catabolism, which results in lower HDL levels (Pietzsch et al., 1998).

\section{A Socioeconomics Characters of MetS Type 2 diabetic Patients}

Table (2) shows socioeconomic characters of MetS type 2 diabetic patients. The prevalence of MetS in females was about 9 times higher (64\%) than males (7\%), $57 \%$ of MetS were married, and the number of family members is more than 5 members (35\%).

Table 1. Prevalence of the individual components of MetStype 2 diabetic patients (NCEP/ ATP111) *

\begin{tabular}{lccc}
\hline Sex type & Male & Female & Total \\
\cline { 2 - 4 } & $\mathbf{7}$ & $\mathbf{6 4}$ & $\mathbf{7 1}$ \\
\hline Component of Metabolic Syndrome (MetS) ** & Mean \pm S.D (MetS) & \multicolumn{2}{c}{ Metabolic Syndrome (MetS) } \\
& & No (frequency) & $\%$ \\
FBS mg/ml & $181.08 \pm 54.52$ & 71 & 71 \\
wc cm & $112.41 \pm 19.18$ & 65 & 65 \\
TG mg/d & $165.27 \pm 60$ & 47 & 47 \\
HDL mg/dl & $38.8 \pm 15$ & 39 & 39 \\
BP mm Hg & $140 / 100 \pm 20$ & 36 & 36 \\
\hline
\end{tabular}

*National Cholesterol Education Program / Adult Treatment Panel (NCEP/ ATP111) (Lorenzo et al., 2003).

**MetS $71 \%$ ( Patient which havethree or more ofthe five components) 
Table 2. Socioeconomics Characters of MetStype 2 diabetic patients

\begin{tabular}{|c|c|c|c|c|c|}
\hline \multicolumn{2}{|l|}{ Socioeconomics Characters } & \multirow{2}{*}{$\begin{array}{l}\begin{array}{l}3 \text { or more } \\
\text { (MetS) } \\
(\mathrm{n}=71)\end{array} \\
\text { No. }(\%)\end{array}$} & \multirow{2}{*}{$\begin{array}{l}\begin{array}{l}2 \text { or less } \\
\text { (Non }- \text { MetS) } \\
(\mathrm{n}=29)\end{array} \\
\text { No }(\%)\end{array}$} & \multirow{2}{*}{$\begin{array}{l}\begin{array}{l}\text { Total } \\
(n=100)\end{array} \\
\text { No. }(\%)\end{array}$} & \multirow{2}{*}{$\begin{array}{c}\begin{array}{c}P \\
\text { Chi }\end{array} \\
\text { No. \% } \\
\end{array}$} \\
\hline & & & & & \\
\hline \multirow[t]{2}{*}{ Sex Type } & Male & 7 & 11 & 18 & **10.99 \\
\hline & Female & 64 & 18 & 82 & \\
\hline \multirow[t]{4}{*}{ Material Status } & Married & 57 & 21 & 78 & \multirow{4}{*}{2.7} \\
\hline & Single & 4 & 0 & 4 & \\
\hline & Widow & 8 & 8 & 16 & \\
\hline & Divorced & 2 & 0 & 2 & \\
\hline \multirow{3}{*}{$\begin{array}{l}\text { Number of family } \\
\text { members }\end{array}$} & Less than 3 & 11 & 8 & 19 & \multirow{3}{*}{4.343} \\
\hline & $3-5$ & 25 & 13 & 38 & \\
\hline & More than 5 & 35 & 8 & 43 & \\
\hline \multirow[t]{5}{*}{ Age (years) } & $20-30$ & 2 & 0 & 2 & \multirow{5}{*}{7.844} \\
\hline & $30-40$ & 9 & 10 & 19 & \\
\hline & $40-50$ & 20 & 5 & 25 & \\
\hline & $50-60$ & 30 & 12 & 42 & \\
\hline & $\geq 60$ & 10 & 2 & 12 & \\
\hline \multirow[t]{6}{*}{ Education Level } & Illiterate & 29 & 7 & 36 & \multirow{6}{*}{$11.264 *$} \\
\hline & Read and write & 13 & 3 & 16 & \\
\hline & Primary & 4 & 2 & 6 & \\
\hline & Preparatory & 6 & 2 & 8 & \\
\hline & Secondary & 13 & 5 & 18 & \\
\hline & University & 6 & 10 & 16 & \\
\hline \multirow[t]{2}{*}{ Employment Status } & Work & 22 & 10 & 32 & \multirow[t]{2}{*}{3.089} \\
\hline & Doesn't Work & 49 & 19 & 68 & \\
\hline \multirow[t]{2}{*}{ Occupation $(n=32)$} & Literal & 4 & 2 & 6 & \multirow[b]{2}{*}{0.163} \\
\hline & Professionals & 15 & 11 & 26 & \\
\hline \multirow[t]{2}{*}{ Family Income Per month } & Less than L.E.2000 & 48 & 15 & 63 & \multirow{2}{*}{$* * 8.191$} \\
\hline & L.E. 2000 -L.E. 4000 & 23 & 14 & 37 & \\
\hline
\end{tabular}

Significant at 0.05 * Significant at $0.01 \%$

Regarding age, individuals in the 50-60 age group had the highest prevalence of MetS (30\%), while individuals aged 20-30 years and above had the lowest prevalence (2\%). Depending on the level of education, it was observed that most of those who were illiterate (29\%), and $49 \%$ of patients with MetS were unemployed, and the result also showed that the nature of professional work represented a large proportion of the total sample reached $81.2 \%$, as for the level of Monthly income, the results showed that $63 \%$ of the monthly income of the participants was from the family less than 2000 pounds, and that $37 \%$ of the monthly income of the participants was between $2000-4000$ pounds. Which was consistent with previous studies (Felix Fall et al., 2008 and Ford et al. 2002)? The cause of these results may be a relatively unstable lifestyle because most women are unemployed or may be caused by genetic factors.
There was a significantly higher prevalence of MetS among diabetics with a lower educational level (Table 2 ), which is the result of a similar study by Moebus et al., (2007) and Fan et al., (2013). It was found that diabetics with primary education $(14.94 \%)$ and those who were in secondary school or from the four levels $(56.32 \%)$ were more prevalent compared to upper secondary school. (3.45\%) diabetics with high level $(12.64 \%)$. where the value of Chi square was a significant for sex type, education level and family income.

\section{Medical history of MetS Type 2 Diabetic patients}

Data in Table (3) showed that $43 \%$ of metabolic samples were diagnosed with T2DM more than 5 years ago, and when they were asked about the age of diagnosis with T2DM for the first time, the study 
showed that $32 \%$ of metabolic samples were $40-50$ years old.

On the whole, $38 \%$ of metabolic patients accidentally detected the disease. Regarding the family history of T2DM, the study showed that $25 \%$ of metabolic patients have a positive family history and $14 \%$ of them whose mothers have diabetes. Where the value of the chi square was significant for the duration of the disease and the age at the detected disease. Family history has been reported to contribute to speeding up the acquisition of MetS (Lewis et al., 2005).

Table (4) showed that the medical history of type 2 diabetes of MetS, the results indicated that 24\% of metabolic syndrome patients believe that psychological stress was the main cause of their disease. About the use of anti-diabetic medications, $66 \%$ of metabolic samples used anti-diabetic medications.

The study also showed that $37 \%$ of metabolic samples used oral tablets. It also showed that $12 \%$ of metabolic samples used combination therapy for insulin and oral tablets. Regarding the frequency of medications, $20 \%$ of metabolism used a single daily dose of oral tablets, $16 \%$ of the metabolic syndrome patient's time from metabolic syndrome from the medication dose after a meal, and $12 \%$ of metabolic syndrome that took insulin of moderate effect, preferring take insulin before a meal. Where the value of Chi square was a non-significant.

\section{Nutritional Practices of the subjects:}

Table (5) clarifies that $47 \%$ of metabolic sample consume three meals per day. Concerning patients of metabolic, $50 \%$ of the tested samples consume moderate average of fats. $36 \%$ of metabolic patients drink fenugreek as it assists in controlling diabetes ranges. In addition, $45 \%$ of metabolic syndrome sample consume whole wheat bread; whereas $26 \%$ of metabolic samples consume two leaves of bread per day, as the value of Chi square was significant in the rates of bread consuming, while $28 \%$ of metabolic sample consume medium fat meat. $25 \%$ of metabolic sample consume skim milk.

The results (table (5)) elaborate that $24 \%$ of metabolic sample prefer baking, where as $17 \%$ prefer boiling. Concerning consuming the preferred type of protein, such as legumes, red meat, white meat, fish and eggs, the data clarifies that $25 \%$ of metabolic patients obtain their protein from white meat. Concerning the preferred cheese type in case of metabolism $41 \%$ of the participants prefer Quraysh cheese. Metabolic sample prefer $31 \%$ fruit or snacks, while $18 \%$ of the samples prefer sweets between the main meals.

Table 3. Medical history of MetS type 2 diabetic patients

\begin{tabular}{|c|c|c|c|c|c|}
\hline Parameters & & $\begin{array}{l}\text { MetS } \\
(71 \%)\end{array}$ & $\begin{array}{l}\text { Non- } \\
\text { MetS } \\
(29 \%) \\
\end{array}$ & $\begin{array}{l}\text { Total } \\
(n=100) \\
(\%)\end{array}$ & Chi \\
\hline \multirow{4}{*}{$\begin{array}{l}\text { Duration of } \\
\text { The disease }\end{array}$} & Less than a year & 10 & 6 & 16 & \multirow{4}{*}{$7.938 *$} \\
\hline & $1<3$ years & 15 & 8 & 23 & \\
\hline & $3-5$ years & 3 & 5 & 8 & \\
\hline & More than 5 years & 43 & 10 & 53 & \\
\hline \multirow{3}{*}{$\begin{array}{l}\text { Age at } \\
\text { Illness detected }\end{array}$} & $30-40$ years & 19 & 11 & 30 & \multirow[t]{3}{*}{$1.408^{*}$} \\
\hline & $40-50$ years & 32 & 10 & 42 & \\
\hline & More than 50 years & 20 & 8 & 28 & \\
\hline \multirow{3}{*}{$\begin{array}{l}\text { How the disease } \\
\text { detected }\end{array}$} & Accidentally & 38 & 18 & 56 & \multirow{3}{*}{0.738} \\
\hline & Periodic detection & 10 & 4 & 14 & \\
\hline & Appearance of some other symptoms & 23 & 7 & 30 & \\
\hline \multirow{2}{*}{$\begin{array}{l}\text { Presence of diabetes in } \\
\text { the family }\end{array}$} & Yes & 25 & 12 & 37 & \multirow[t]{2}{*}{0.336} \\
\hline & No & 46 & 17 & 63 & \\
\hline \multirow{3}{*}{$\begin{array}{l}\text { Family member has } \\
\text { diabetes }\end{array}$} & Father & 8 & 2 & 10 & \multirow{3}{*}{1.277} \\
\hline & Mother & 14 & 9 & 23 & \\
\hline & Grandparents from father & 3 & 1 & 4 & \\
\hline
\end{tabular}

*Significant at 0.05 
Table 4. The causes of diabetes and medications for MetS type 2 diabetic patients

\begin{tabular}{|c|c|c|c|c|c|}
\hline Parameters & & $\begin{array}{c}\text { Metab } \\
\text { olic } \\
\mathbf{7 1 \%}\end{array}$ & $\begin{array}{c}\text { Non- } \\
\text { metabolic } \\
29 \%\end{array}$ & $\begin{array}{l}\text { Total } \\
100 \%\end{array}$ & Chi \\
\hline \multirow[t]{5}{*}{ Causes of diabetes } & Genetics & 16 & 9 & 25 & \\
\hline & Lifestyle & 8 & 4 & 12 & 4.157 \\
\hline & Wrong dietary Practices & 16 & 8 & 24 & \\
\hline & Psychological stress & 24 & 4 & 28 & \\
\hline & I don't Know & 7 & 4 & 11 & \\
\hline \multirow[t]{2}{*}{ Anti diabetic medications } & Yes & 66 & 28 & 94 & 0.472 \\
\hline & No & 5 & 1 & 6 & \\
\hline \multirow[t]{3}{*}{ Type of anti diabetic medication } & Oral tablet & 37 & 17 & 54 & \\
\hline & Insulin & 17 & 7 & 24 & 0.254 \\
\hline & Both of them & 12 & 4 & 16 & \\
\hline \multirow[t]{3}{*}{ Medicine dose / day } & Once & 20 & 8 & 28 & \\
\hline & Twice & 12 & 10 & 22 & 1.036 \\
\hline & Three times & 4 & 0 & 4 & \\
\hline \multirow[t]{3}{*}{ Time of medicine dose } & Before meal & 15 & 10 & 25 & \\
\hline & Middle of meal & 4 & 5 & 9 & 1.863 \\
\hline & After meal & 16 & 4 & 20 & \\
\hline \multirow[t]{3}{*}{ Insulin effect } & Long effect & 3 & 2 & 5 & \\
\hline & Medium effect & 12 & 4 & 16 & 0.820 \\
\hline & Short effect & 3 & 0 & 3 & \\
\hline \multirow[t]{3}{*}{ Time of Insulin } & Before meal & 12 & 6 & 18 & 1.935 \\
\hline & Middle of meal & 1 & 1 & 2 & \\
\hline & After meal & 3 & 1 & 4 & \\
\hline
\end{tabular}

Archer et al., (2004) and Yeung et al . (2018) assert that consuming poultry, meat, rice, and full-fat milk in large quantities increases diabetes ranges in blood. Thus, it is necessary to consume low-fat meats; in addition, saturated fats must not exceed $10 \%$ in the meals of diabetes's patient and it is better to use nonsaturated fats.

Protein is regarded a very important element in the healthy meal as it does not increase diabetes rates. Meat, eggs, diary, poultry, and fish are regarded very important sources for protein (Clemente et al., 2018).

Here, it is better for diabetes's patient to have complex carbohydrate like full grain and not to have more than $10 \%$ of simple sugars (Thomas et al., 2017).

Eckel et al. (1995) stated that individuals should advised to practice more exercise and eat foods that contain small amounts of saturated fat, cholesterol, refined sugars and eat more high-fiber foods. Having high-fiber diets can improve their glycemic index, which can reduce plasma fasting glucose level, total cholesterol and triglycerides.

Table (6) shows nutritional practices levels of MetS type 2diabetic patients the results indicated that $12 \%$ of metabolic patients had a poor nutritional practices level, $14 \%$ had a good, and $45 \%$ had a moderate. In the other hand the nutritional practices in non- metabolic were $4 \%$ poor, $19 \%$ moderate and $6 \%$ good; the nutritional practices overall mean for all sample were $(41 \pm 5)$, and the differences were not statistically significant. 
Table 5. The differences in nutritional practices between MetS and non MetS type 2 diabetic patients

\begin{tabular}{|c|c|c|c|c|c|}
\hline Nutritional Practices & & $\begin{array}{l}\text { MetS } \\
(71 \%)\end{array}$ & $\begin{array}{l}\text { Non-metS } \\
(29 \%)\end{array}$ & $\begin{array}{c}\text { Total } \\
(100 \%)\end{array}$ & Chi \\
\hline \multirow[t]{3}{*}{ Meal Number } & Two & 15 & 2 & 17 & \multirow{3}{*}{4.167} \\
\hline & Three & 47 & 20 & 67 & \\
\hline & More than three & 9 & 7 & 16 & \\
\hline \multirow[t]{3}{*}{ Fat Content } & Low & 9 & 3 & 12 & \multirow{3}{*}{0.906} \\
\hline & Medium & 50 & 23 & 73 & \\
\hline & High & 12 & 3 & 15 & \\
\hline \multirow{5}{*}{$\begin{array}{l}\text { Herbal beverages help in diabetes } \\
\text { management }\end{array}$} & Green tea & 24 & 15 & 39 & \multirow{5}{*}{6.354} \\
\hline & Fenugreek & 36 & 13 & 49 & \\
\hline & Fennel & 1 & 1 & 2 & \\
\hline & Cinnamon & 8 & 0 & 8 & \\
\hline & Ginger & 2 & 0 & 2 & \\
\hline \multirow[t]{3}{*}{ Type of bread } & Refined wheat & 13 & 4 & 17 & \multirow[t]{3}{*}{0.323} \\
\hline & Whole wheat & 45 & 19 & 64 & \\
\hline & Unrefined & 13 & 6 & 19 & \\
\hline \multirow[t]{4}{*}{ Bread consumption(number / day) } & One & 12 & 10 & 22 & \multirow{4}{*}{$8.695 * *$} \\
\hline & Two & 26 & 4 & 30 & \\
\hline & Three & 17 & 11 & 28 & \\
\hline & Four and more & 16 & 4 & 20 & \\
\hline \multirow{3}{*}{ Type of meat } & Fat-free & 35 & 14 & 49 & \multirow{3}{*}{4.460} \\
\hline & Medium fat & 28 & 15 & 43 & \\
\hline & High fat & 8 & 0 & 8 & \\
\hline \multirow[t]{3}{*}{ Milk Type } & Skimmed Milk & 25 & 10 & 35 & \multirow{3}{*}{0.512} \\
\hline & Semi-Fat & 41 & 18 & 59 & \\
\hline & Whole Milk & 5 & 1 & 6 & \\
\hline \multirow[t]{6}{*}{ Favorite cooking way } & Boiling & 17 & 9 & 26 & \multirow{6}{*}{8.99} \\
\hline & Roasting & 9 & 6 & 15 & \\
\hline & Reddish & 4 & 4 & 8 & \\
\hline & Frying & 10 & 1 & 11 & \\
\hline & Sticking & 7 & 5 & 12 & \\
\hline & Baking & 24 & 4 & 28 & \\
\hline \multirow{5}{*}{ Favorite type of protein } & Legumes & 8 & 4 & 12 & \multirow{5}{*}{6.352} \\
\hline & Red meat & 7 & 7 & 14 & \\
\hline & White meat & 25 & 12 & 37 & \\
\hline & Fish & 23 & 4 & 27 & \\
\hline & Eggs & 8 & 2 & 10 & \\
\hline \multirow[t]{3}{*}{ Favorite cheese type } & White & 26 & 12 & 38 & \multirow{3}{*}{2.473} \\
\hline & Quraish & 41 & 13 & 54 & \\
\hline & Cheddar and Turkey & 4 & 4 & 8 & \\
\hline \multirow[t]{6}{*}{ Favorite food between meals } & Fruit & 31 & 19 & 50 & \multirow{6}{*}{7.235} \\
\hline & Vegetables & 9 & 5 & 14 & \\
\hline & Sweets & 18 & 4 & 22 & \\
\hline & Biscuit & 5 & 1 & 6 & \\
\hline & Bakery & 4 & 0 & 4 & \\
\hline & Snacks & 4 & 0 & 4 & \\
\hline
\end{tabular}

** Significant at 0.01 
Table 6. Nutritional practices levels of MetStype 2 diabetic patients

\begin{tabular}{lllcccc}
\hline $\begin{array}{l}\text { Nutritional } \\
\text { Practices }\end{array}$ & $\begin{array}{l}\text { MetS } \\
\mathbf{( 7 1 \% )}\end{array}$ & $\begin{array}{l}\text { Mean } \\
\mathbf{\pm S . D}\end{array}$ & $\begin{array}{c}\text { Non-MetS } \\
\mathbf{( 2 9 \% )}\end{array}$ & Mean \pm S.D & $\begin{array}{c}\text { Total } \\
(\mathbf{n = 1 0 0}) \\
(\boldsymbol{\%})\end{array}$ & chi-test \\
\hline Poor & 12 & & 4 & & 16 & \\
Moderate & 45 & & 19 & $41 \pm 5$ & 50 & \\
Good & 14 & $41 \pm 5$ & 6 & & 34 & 0.149 \\
Total & 71 & & 29 & & 100 & \\
\hline
\end{tabular}

Minimum degree (15)

Maximum degree (29)

\section{CONCLUSION}

This study indicated that approximately $71 \%$ of the type 2 diabetes patients had MetS. The 50-60 age group was the most prevalent of MetS and females were about 9 times higher $(90.1 \%)$ than males, and the most prevalent components were central obesity $(65 \%)$, followed by high TG (47\%) and low HDL (39\%). Educational levels, working status, profession, and household income per month have a significant impact on the level of nutritional practices for type 2 diabetes patients with MetS.

The study showed that $12 \%$ of metabolic syndrome patients had a poor level of nutritional practices, and $14 \%$ had good, $45 \%$ had moderate.

\section{RECOMMENDATION}

Our findings indicated that metabolic syndrome had become a common public health problem, and therefore, we need to develop strategies, which aim to prevent and treat the metabolic syndrome, such as changing lifestyle, nutritional habits, increase physical activity and weight control.

\section{REFERENCE}

Alberti, K. G., M. M. P. Zimmet, and J. Shaw. 2006. Metabolic syndrome - a new world-wide definition. A consensus statement from the international diabetes federation. Diabetic medicine. 23(5):469-480.

Allain, C.C. 1974. Cholestrol enzymatic colorimetric method. J.of Clin. Chem. 20: 470.

American Heart Association /National Heart, Lung, and Blood Institute Scientific Statement. 2012. Diagnosis and Management of the Metabolic Syndrome. Circulation. 39: 60-72.

Archer, S., K. Greenland, R. Valdez, M. Casper,; RithNajarian and J.Croft. 2004. Differences in food habits and cardiovascular disease risk factors among Native Americans with and Without diabetes: The Inter-Tribal Heart Project. Public Health Nutr. 7(8): 1025-1032.
Chandalia, M., A. Garg, D. Lutjohann, K.. von Bergmann, S.M. Grundy and L.J. Brinkley. 2000. Beneficial effects of high dietary fiber intake in patients with type 2 diabetes mellitus. N Engl J Med. 342: 1392-8.

Clemente, G., M. Gallo, M. Giorgini, behalf of the AMDO.Associazione and M. Diabetologi. 2018. Modalities for assessing the nutritional status in patients with diabetes and cancer. Diabetes research and clinical practice. 142: 162- 172 .

Eckel, R.H., T.J. Yost and D.R. Jensen. 1995. Alterations in lipoprotein lipase in insulin resistance. Int $\mathrm{J}$ Obes Relat Metab Disord. 19(1): S16-21.

Fan, A.Z. and Y.B. Zhou. 2013. 1st ed. New York: Humana Press; Alcohol, Nutrition and Health Consequences: Alcohol Intake and High Blood Pressure. 321-7

Felix-Val, K., W.K. Titty, W.K.Owiredu and M.T. AgyeiFrimpong. 2008. Prevalence of metabolic syndrome and its components among diabetes patients in Ghana. J Biol Sci. 8:1057-61.

Ferrannini. E. 1995. Physiological and metabolic sequences of obesity. Metabolism. 44(3):15-7.

Fossati, P. and L. Principe. 1982. Determination of triglycerides.Clinical Chemistry. 28: 2077-2078.

Ford,E.S., W.H. Giles, and W.H. Dietz. 2002. Prevalence of the metabolic syndrome among US aldults: findings from the third National Health and Nutrition Examination Survey .Jama. 287(3):356-359.

Ginsberg, H.N. and P.R. MacCallum. 2009. The Obesity, Metabolic Syndrome, and Type 2 Diabetes Mellitus Pandemic: Part I. Increased Cardiovascular Disease Risk and the Importance of Atherogenic Dyslipidemia in Persons with the Metabolic Syndrome and Type 2 Diabetes Mellitus :2(4):113-119.

Grundy, S.M., J.I, Cleeman, S.R. Daniels, K.A. Donato, R.H. Eckel and B.A.Franklin, D.J. Gordon., R.M. Krauss, P.J. Savage. J.A.Smithjr and F. Costa. 2005. Diagnosis and management of the metabolic syndrome:. Circulation. 112 (17): 2735-52.

Lewis, G.F. and D.J. Rader. 2005. New insights into the regulation of HDL metabolism and reverse cholesterol transport. Circ Res. 96:1221-32.

Lesser, I .A, D. Gasevic and S.A. Lear. 2014. The Association between Acculturation and Dietary Patterns of South Asian Immigrants, PLoS One. 9(2): 488-495. 
Lorenzo, C., M. Okoloise, K. Williams, M.P. Stern and S.M. Haffner. 2003. The metabolic syndrome as predictor of type 2 diabetes the San Antonio Heart Study. Diabetes Care. 26 (11): 3153-9.

Pietzsch, J., U. Julius, S. Nitzsche and M. Hanefeld. 1998. In vivo evidence for increased apolipoprotein A-I catabolism in subjects with impaired glucose tolerance. Diabetes. 47:1928-34.

Malhotra, V.K. 2003. Practical Biochemistry for Students. Fourth Edition Jaypee Brothers Medical Publishers (P) LTD. New Delhi

Moebus, S., J.U. Hanisch, P. Aidelsburger, P. Bramlage, J. Wasem and K.H. Jöckel. 2007. Impact of 4 different definitions used for the assessment of the prevalence of the Metabolic Syndrome in primary healthcare: The German Metabolic and Cardiovascular Risk Project (GEMCAS) Cardiovascular Diabetology. 6 (1): 22.

Nsiah, K., V. O.Shang, K. A.Boateng and F. O. Mensah. 2015. Prevalence of metabolic syndrome in type 2 diabetes mellitus patients. International Journal of Applied and Basic Medical Research. 5(2):133.

Negrato, A.C., A.K. Davison and B.M. Gomes. 2014 Relationship between adherence to diet, glycemic control and cardiovascular risk factors in patients with type 1 diabetes: Nutrition j. 19 (13):4855.

Richmond, W. 1973. Preparation and properties of a cholesterol oxidase from Nocardia sp. and its application to the enzymatic assay of total cholesterol in serum. Clin.Chem. 19 (12): 1350
Shin, J.A, J.H. Lee, S. Y. Lim, H.S. Ha, H. S. Kwon, Y.M. Park, W.C. Lee, M.I.Kang, H.W.Yim, K.H.Yoon, H.Y.Son. 2013. Metabolic syndrome as a predictor of type 2 diabetes, and its clinical interpretations and usefulness, J Diabetes Investig. 4(4):334-343.

Thomas, A. M. and M. Duarte-Gardea. 2017. Nutritional Management for Gestational Diabetes. In Nutrition in the Prevention and Treatment of Disease (Fourth Edition). 709-729.

Wang, T., Y.Takikawa, T. Satoh, Y.Yoshioka, K. Kosaka, Y.Tatemichi and K.Suzuki. 2014. Carnosic acid prevents obesity and hepatic steatosis in $o b / o b$ mice. Hepatology Research. 41: 87-92.

Wilson, P.W., R.B. D’Agostino, H.Parise, L. Sullivan and J.B. Meigs. 2005. Metabolic syndrome as a precursor of cardiovascular disease and type 2 diabetes mellitus. Circulation. 112:3066-72.

Walker, R.B. 2006. Cortisol-cause and cure for metabolic syndrome?. J. compilation, Diabetes UK. Diabetic Medicine. 23:1281-1288.

Yeung, S., J.Soliternik and N.Mazzola. 2018. Nutritional Supplements for the Prevention of Diabetes Mellitus and Its Complications. J. of Nutrition and Intermediary Metabolism. 


\section{الملخص العربي}

\section{انتشار المتلازمة الأيضية: العوامل المرتبطة، الممارسات الغذائية بين مرضى السكرى النوع الثانى}

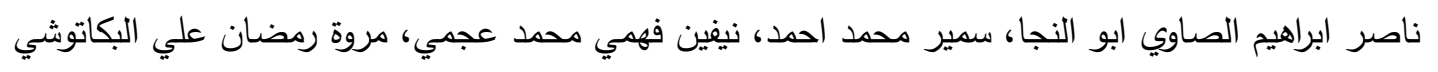

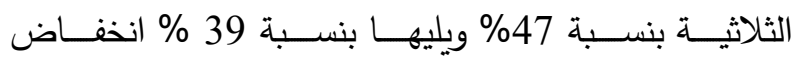
البروتينات الدهنية عالية الكثافة.

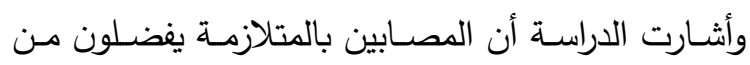

طرق الطهى الخبز بالفرن بنسبة 24\% ويليها السلق بنسبة 17\% بينما الغير مصابين بالمتلازمة يفضلون السلق بنسبة بالفية

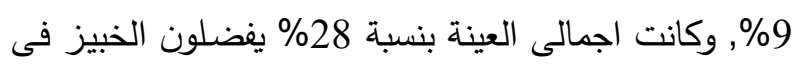

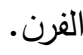

كمـا تبين أن مرضـى المتلازمــة يفضـلون بين الوجبـات

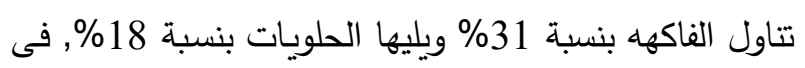
حين كان غير المصابين بالمتلازمة يتتاولوا الفاكهة بنسبة 19\% يليها الخضروات بنسبة 5\% بين الوجبات.

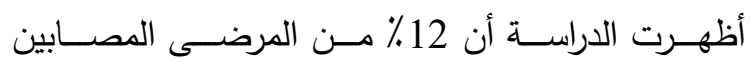

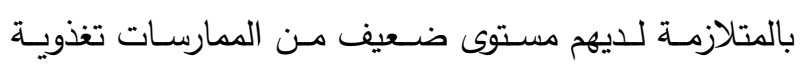
و14\% لديهم ممارسات تغذوية جيدة و45\% لديهم ممارسات تغذوية متوسطة.

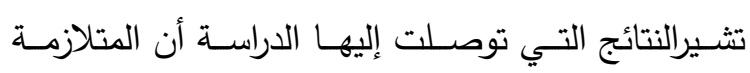

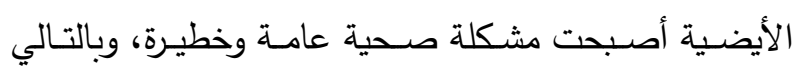

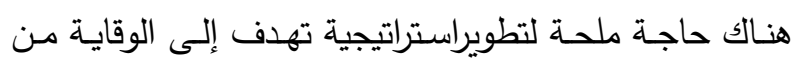
الإصابة بالمتلازمة الأيضية وكذلك معالجتها.
تهـف هذه الدراسـة إلى تحديد مدى إنتشـار المتلازمــة

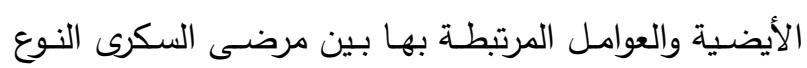
الثانى والتعرف علي أهم الممارسات الغذائية لهم. شملت هذه الدراسة 100 مريض سكرى من النوع الثانى

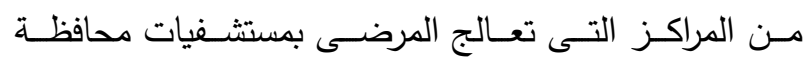
الاسكندرية وذلك خـلال الفترة من يونيو 2018 حتى فبراير 2019 وقد تم جمع البياتات والحصول على المعلومات عن طريق الإستبيان بالمقابلة الثخصية وتضمنت بنود الاستبيان

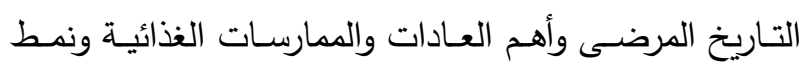
الحياه الخاص بهم، وتم تقدير بعض المقاييس الجسمية أههها

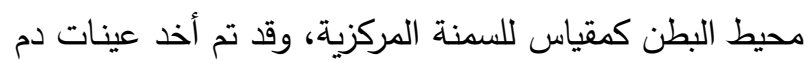
لعهل بعض المقاييس الكيميائيسة الحيويـه مثل (سكر الدام

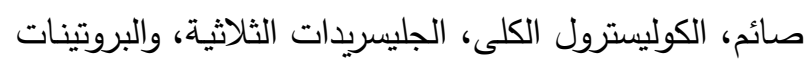

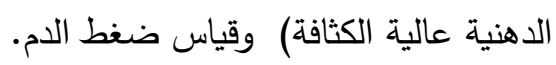
وأوضحت النتائج أن 71\% من مرضى السكرى من النوع

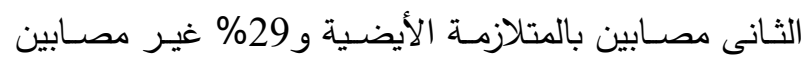

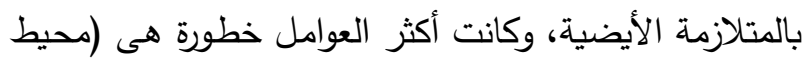

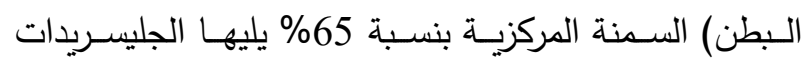

